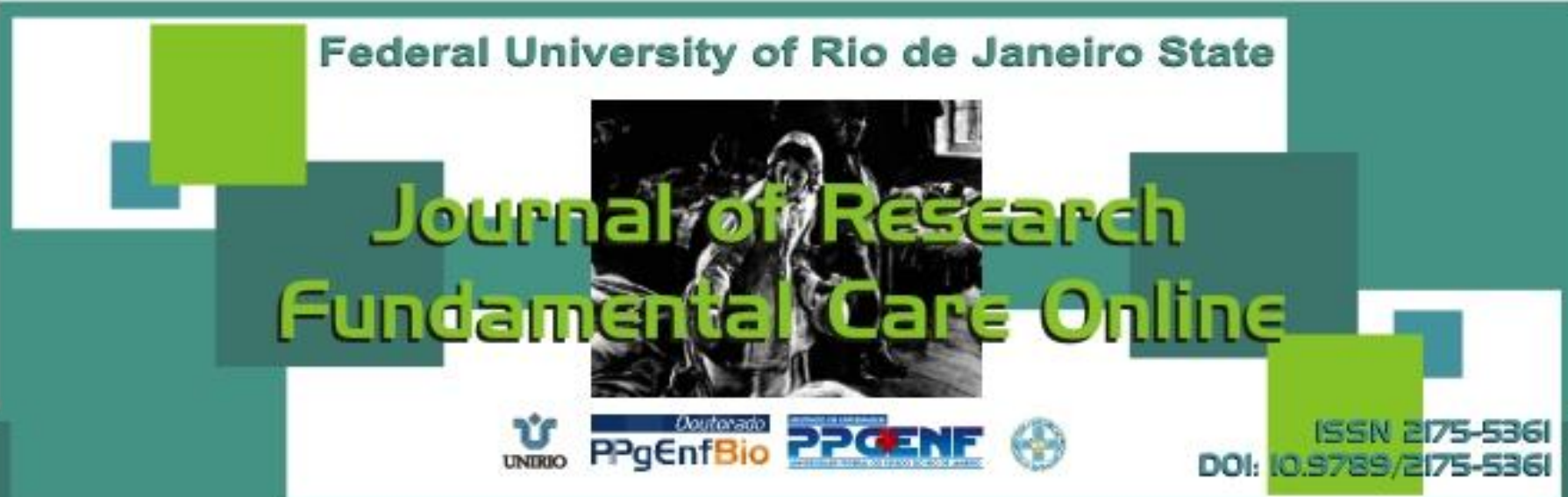

\title{
RESEARCH
}

\section{The complexity of the nursing work in hospiatl for custody and psychiatric treatment}

A complexidade do trabalho de enfermagem no hospital de custódia e tratamento psiquiátrico

La complexidad del trabajo de enfermería en el hospital de custodia y tratamiento psiquiátrico

Geilsa Soraia Cavalcanti Valente ${ }^{1}$, Fernanda Souza Santos ${ }^{2}$

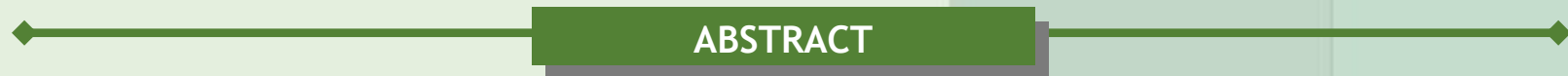

Objective: to analyse the ways in which professional nurses to lead with the complexity of the work at the Hospital for Custody and Psychiatric Treatment. Method: Descriptive and qualitative research with 15 professional nurses. Data collection occurred through the semi-structured interview, and thematic analysis content. Results: the main prevention and protection strategy to the health worker's was the interdisciplinarity in the actions. Conclusion: it was evidenced the need for educational measures to define the role of the Hospital for Custody and Psychiatric Treatment in society and in the psychotic offenders lives and the restructuring of work organization in an interdisciplinary way to became in opportunities of creation and realization to the worker, regarding to their physical and mental apparatus. Descriptors: Nursing, Interdisciplinarity, legalPsychiatry, Prisons.

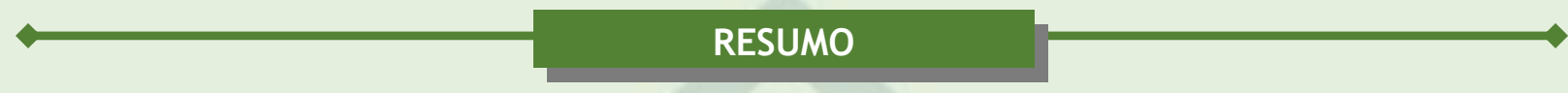

Objetivo: analisar as formas com que os profissionais de enfermagem lidam com a complexidade do trabalho no Hospital de Custódia e Tratamento Psiquiátrico. Método: pesquisa qualitativa descritiva, tendo como sujeitos 15 trabalhadores de enfermagem. A coleta de dados se deu por intermédio da entrevista semiestruturada e análise temática de conteúdo. Resultados: a principal estratégia de proteção e prevenção à saúde do trabalhador foi a interdisciplinaridade nas ações. Conclusão: evidenciou-se a necessidade de medidas educativas voltadas para a definição do papel do Hospital de Custódia na sociedade e na vida dos psicóticos infratores, e a reestruturacão da organizacão do trabalho de forma interdisciplinar, a fim de que este se converta em possibilidades de criação e realização para o trabalhador, no que diz respeito ao seu aparelho físico e psíquico. Descritores: Enfermagem, Interdisciplinaridade, Psiquiatria legal, Prisões.

\section{RESUMEN}

Objetivo: analizar las maneras como los profesionales de enfermería lidia con la complejidad del trabajo en el Hospital de Custodia y Tratamiento Psiquiátrico. Método: investigación cualitativa y descriptiva, teniendo como sujetos 15 trabajadores de enfermería. La recopilación de los datos se produjo por medio de una entrevista semiestructurada, y análisis temático de contenido. Resultados: la principal estrategia de prevención y protección a la salud de los trabajadores, fue la interdisciplinariedad en las acciones. Conclusión: se evidenció la necesidad de medidas educativas, destinadas a definir el papel del Hospital de Custodia en la sociedad y en la vida de los delincuentes psicóticos y la reestructuración de la organización del trabajo de manera interdisciplinar, con el fin que se convierta en posibilidades de creación y realización para el trabajador, con respecto a su aparato físico y mental. Descriptores: Enfermería, Interdisciplinariedad, Psiquiatría legal, Cárceles.

${ }^{1}$ Enfermeira. Doutora em Enfermagem; Professora Adjunta do Departamento de Fundamentos de Enfermagem e Administração da Escola de Enfermagem Aurora de Afonso Costa - Universidade Federal Fluminense - EEAAC/UFF. Niterói (RJ). E-mail: geilsavalente@yahoo.com.br. ${ }^{2}$ Enfermeira. Mestre em Enfermagem. Mestrado profissional em Enfermagem Assistencial. Escola de Enfermagem Aurora de Afonso Costa - Universidade Federal Fluminense - EEAAC/UFF. Niterói (RJ). E-mail: nandasimpatica@yahoo.com.br. 


\section{INTRODUCTION}

he scenario where the work process is developed, can also influence work relations and the construction of this interrelation could be compromised if the involved in this process are unable to break away from the historical influences, organizational, environmental, of the served clientele and the own characteristics of each professional.

The attention to the population health of the prison system, is in the Unified Health System (SUS) ${ }^{1}$, by the Inter ministerial Ordinance $n^{\circ} 1.777^{2}$, ensuring the effect of the citizenship right of people governed by the State. Bringing this context the Hospital of Custody and Psychiatric Treatment, (HCTP), evidencing its characteristics and peculiarities, where the worker process takes place in a confinement area and with rules and routines fairly rigid, as it happens in a total institution ${ }^{3}$, may be more complex for the teams, having an interdisciplinary look.

The HCTP is a prison-hospital, penal establishment, which seeks to ensure custody and internal treatment. Has, in essence, its ambivalent and ambiguous character's, since groups hospital characteristics, such as health team, wards, nurses 'stations, medical care rooms, therapeutic workshops and, at the same time, presidio features, evidenced by a whole security system composed by guards team, high walls with wire, iron gates, grilles on doors and windows and locks. ${ }^{4}$

The State of penal institutions creation has the purpose to protect the population of those who might represent some kind of threat or danger and, one of the goals of someone undergoing a sentence of liberty deprivation, is that removing of social conviviality, somehow, the System will help to ensure the internal, to pay off his debt to society, and to get conditions of social reintegration.

In this context, the private freedom institutions needed to develop mechanisms to meet not only the demand of society, but also of its own subjects, i.e. it was necessary for the State to create support mechanisms to the health needs of this clientele, inscribed in the security measure. ${ }^{5}$

The therapeutic treatment is done by nursing staff, psychiatrists, occupational therapy, psychology, social work, general clinic, cardiology and yet, legal assistance. For being a prison institution, it has a security system consisting of prison staff responsible for maintaining discipline and order in the institution. ${ }^{6}$

The complexity of the relationships among the health workers is another complicating factor. These professionals are a unique human being, a particular I, that have different problems and difficulties. This difference generates many conflicts in the relationship with other professionals or even in the own profession. It is known that each one has their needs and ways of seeing the world, triggering many point of view about the same focus, the human being. ${ }^{7}$ 
In this perspective, the health professionals have a fundamental role in the formation of this context, which requires communication and dialogue between the occupational categories. However, these different ways of thinking and acting can cause differences of opinion, setbacks and difficulties in the teamwork. The academic training contributes to that, because there is little interchange of ideas between the disciplines. ${ }^{7}$

The interdisciplinary is therefore a challenge by the complexity of the health-disease process, implying the development of creative imagination in the process of care. ${ }^{8}$ In this way, the interdisciplinary presents as a response to the diversity, to the complexity and to the dynamics of today's world. ${ }^{9}$

The context of care in jail situation is permeated by boundary issues, and challenges both the nursing professional, as many other workers must overcome in order to carry out its role in the institution, and in the meantime, the psychotic infringer patient is another key-subject for the employee be able to apprehend this complex scenario and the arrangement of work organization and to have on interdisciplinary an ally for the realization of the principles stated by the psychiatric ${ }^{10}$ reform and by SUS. ${ }^{1}$

To this end, this study had as its objectives: to analyze the ways in which nursing professionals deal with the complexity that exists in confined work environment of HCTP and discuss the strategies used as protection for workers ' health.

\section{METHODOLOGY}

This article is a result of Professional Master of Assistance Nursing dissertation, defended in June 2012, in the Nursing School Aurora of Afonso Costa - Fluminense Federal University, which discusses the topic of occupational health nursing of the Penal System, entitled Imprisoned Care: repercussions on nursing health worker from the Hospital of Custody and Psychiatric Treatment.

This is qualitative research of descriptive type, which is characterized as a systematic inquisition mode, worried about the understanding of human beings and the nature of dealings with themselves and with their surroundings. This type of search is based on the premise that the knowledge about the individuals is only possible with the description of human experience. ${ }^{11}$

One of the primary purposes of the qualitative research, are goals like the description, that when little is known about a group of people, an institution or any social phenomenon, in-depth interviews and participative observation are excellent ways to learn about them. ${ }^{12}$

The research was developed in a Hospital of Custody and Psychiatric Treatment of Rio de Janeiro - RJ, which aims to guard and treat male people, with capacity for 150 inmates, who committed crimes due to mental illness and chemical dependency, from 
police stations, prisons and other public institutions, detained for judicial determination in order to comply with safety measures. ${ }^{6}$

The HCTP is a closed institution, high walls, bars, featuring a total system, symbolized by the barrier to social relationship with the outside world and leaving prohibitions, which are often included in the physical schema, rules, doctrines and tasks to be fulfilled.

The study subjects were the professionals who integrate the nursing staff, namely: nurses, technicians and nursing assistants who work at the Hospital of Custody and Psychiatric Treatment. The study was conducted with the participation of 15 workers, taking as an inclusion criterion the acceptance to participate in the study, and to be working until the date of the data collection.

The data collection lasted from August to September 2011 and through the application of a characterization instrument of the subject and the script by semistructured interview. ${ }^{11}$ The realized questions in the interviews were conducted during the workday in the institution, at times provided, both for the leadership and for the worker.

When the information-gathering phase finished, the collected material was evaluated and transcribed, beginning a careful reading and refined all the available material and later qualitative classification of the information into categories, treated according to thematic analysis of content, which is constituted of a set of techniques used to accomplish the communication by systematic and objectives procedures of the content description of inference message. ${ }^{11}$

The study is in accordance with Resolution No. 196/96, of the National Health Council, which sets norms and guidelines for the research involving human beings. ${ }^{13}$ It was subjected to the Committee of Ethics in Research of the Medicine Faculty of Fluminense Federal University, approved under $n^{\circ}$ CAAE: 0039.0.258.000-11. The participants adhesion occurred by signing a Free Informed Consent Statement which ensures ethical rights, including giving up the participation in the research at any time, without any penalty or prejudice.

It was ought to support the analysis of data collected, using the theoretical references of Cristophe Dejours related to psychic load of work, and of Edgar Morin, inherent in the complexity of work organization, having a relationship to the dangerousness of the Penal System, which is inscribed in the unpredictability of offender subject.

\section{RESULTS AND DISCUSSION}

The interdisciplinary as a Strategy to Work at the Hospital of Custody and Psychiatric Treatment.

The dangerousness of the Criminal System can be understood as the violence representation configured in the prison population, in the tension characterized by the need 
to guard the prisoners. Its unpredictability is contained in the aspirations and future projects, because a prisoner inside the penitentiary has a single goal: the freedom.

The psychopathology of work aims to study, on the other hand, relations among conduct, behaviors, experiences of suffering and pleasure; and another, to study the work organization and social relations of work. ${ }^{14}$ This appears to break with the Taylorist conception of work organization, seeking to understand that such model triggers mental and physical problems in the worker.

From the participants' reports, it was possible to build the category: The interdisciplinary as a Strategy to Work at the Hospital of Custody and Psychiatric Treatment. These category shows, through statements, the need for an articulated work between teams who work in the Hospital of Custody and Psychiatric Treatment, to perform a job based on interdisciplinary and on mutual assistance, to achieve an effective and quality service to this clients.

It is clear, too, that interdisciplinary takes the connotation of interconnected work, that is a tangle complex that would have as a role the cohesion among the professionals of all disciplines who work there, in order not only to attend the clients, but also for the purpose of security and their physical and mental protection. Thus, interdisciplinary work is proposed as a way to deal with the extent and complexity that involves assistance in this field.

For professional relationship, is the relationship among individuals within the team for care, both in relations as a whole, as in individual behaviors and attitudes. Thereby, the interdisciplinary practice involves the planning and execution of patient care in an integrated way among the involved health professionals. ${ }^{15}$

In addition, the personal characteristics of the professionals also compete for good interdisciplinary practice, once that comprise the ability of individuals to relate with each other. The complementarity of these point of view contributes to the change, transformation, suitability or maintenance of models of life understanding, health and sickness, as these groups make decisions on care. ${ }^{7}$

Thus, the Hospital of Custody and Psychiatric Treatment, because of having so different characteristics from other institutions and for answering a clientele that demands not only the provision of health care, but also geared to social and personal needs, that the professional nursing may not have how to deal. So there must not exist the service fragmentation, but have to design a work in conjunction, where interdisciplinary is the master for both professionals and patients are benefited as the testimonials below:

I would like that professionals of other areas interact more with the nursing and put into practice the multi-disciplinarily, this would have to be done, it's all very individualized, so that fractionation in care, in the treatment of the patient ends up harming $[. .$.$] (Deponent 1)$

I really wish the work would be interdisciplinary, that the teams learn to work together, this would facilitate the care and it would be important for our own protection.(Deponent 8) 
[...] there is no interaction between other sectors of the units, everyone is individualized, every one for their own, I think it damages the work, I think if there would be a more joint performance would facilitate. (Deponent 13)

The key-problem may be in a thought that unite this reality the word complexity, because in this context, is so important, where complexes means what is woven together, which gives a feature to tapestry. The complex thought is the thought that strives to unite, not in confusion, but operating differentiations. ${ }^{15}$

On the intentionality of activating the process of completeness, it arises the complexity of integrating subject-object, theory-practice, know-how, personal-public, private-public, local-global, individual-collective. For this, it becomes necessary a permeability between disciplinary borders that incorporates multidimensionality of subjects and contexts. ${ }^{17}$ In this way, the multidisciplinary team would favor the reflection on the professional role and the work process within the institutions, through the spaces of dialogues and perceptions about the activities and the difficulties in the completeness of the actions. ${ }^{17}$

The interdisciplinary is proposing to broaden the worldview, of ourselves and of the reality, with the purpose of overcoming the disciplinary viewpoint. It does not consist to reduce science to a common denominator, destroying its specificity, nor dissolve contents empty formulations that explains nothing. It should be a mediator enabling the understanding of science, in addition to cooperation forms at a level far more critical and creative among scientists. ${ }^{18}$

Under this perspective, and considering significant the implementation of interdisciplinary actions, a statement emerged that signaled the opposite of what is necessary, considering that in practice, according to the deponent, occurs the detachment of professionals, as demonstrated below:

There is a lack of unity among the health professionals who work here. (Deponent 5)

What it is observed from the lines is that the articulation among workers is not a problem, not still being the initiative on the part of its own team and even managers in establishing or developing an educational proposal which aims to interdisciplinary practice in the institution. These reflections on the work processes on health show that the organization can be a producer of both health and illness. Autonomy and institutional responsibility and the workers co-participation in the construction of completeness are connected to the management model. ${ }^{18}$

It was observed that the complexity of the work process in the Hospital of Custody and Psychiatric Treatment is also in the lack of interaction between the teams, in the nonexistence of an interdisciplinary work and even in the isolation between the work sectors. With that, the construction of this knowing set, interdisciplinary, is a philosophical task whose dimension would be incorporation of knowledge and the search for general and common elements of each worker. ${ }^{11}$ This fact implies the commitment of each subject, because the trans-disciplinary is only a solution in case of thought reform. ${ }^{19}$ 
It is a need to replace a thought that separates for a thought that links, and that link requires the replacement of an one-dimensional and one-lineal causality in a circle and multi-referential casualty, as well as the exchange of rigidity of classical logic for a dialogical able to conceive notions at once complementary and antagonistic; that knowledge of the integration of the parts to be completed by the recognition of all integration within the parts. ${ }^{19}$

Increasingly people are closed and do not communicate with each other, the phenomena are increasingly fragmented, and can't conceive their unit. Thus, it becomes important that each intend to recognize its territorial sovereignty, but into the set, so, it is believed that at the expense of conducting trade, the borders are confirmed rather than fall apart. $^{19}$

A deponent signals to the need that feeling of having a space of activeness as nurse, because, according to her, only the other professionals conduct the service while participating in the technical team, considering that not always the nursing professionals are present in decisions inherent in patient care, although are these professionals responsible for them during the whole period of stay.

In this prism, the deponent declares that:

[...] I'd like to sit and be heard by the team that is serving that patient, because you want to do something better for them, because it's you that lives with them 24 hours $[\ldots]($ Deponent 5)

This statement refers to the importance of enhancing the nursing professional, because they remains taking care of patients during the entire period of hospitalization, performs procedures, and others, however, has no power of decision about treatment. This factor also generates professional wear, for not having their opinion respected or considered.

In this experience, from a forced contact with an uninteresting task is born an image of futility. The lacks of signification, the narcissistic frustration, the uselessness of gestures form cycle per cycle, a narcissistic pale image. ${ }^{14}$ To the author, this situation equates to another experience not less present than that of indignity, feelings of worthlessness, which refers primarily to the lack of qualification and work purpose, which, in practice, not always refers to truth, because according to the testimonies, the interdisciplinary work, where everyone has their real stimulated worth, would lead to better care offered to detainees, and would decrease the problems related to the worker's health care. 


\section{CONCLUSION}

The context of care in jail is permeated by limits and challenges issues, both the nursing professional as the remaining workers must overcome in order to carry out its role in the institution, and in the meantime, the psychotic infringer patient is another key-subject to which the employee can learn in this complex scenario the arrangement of work organization and have on interdisciplinary an ally for the realization of the principles stated by the psychiatric reform and by SUS.

Thus, the situational diagnosis points to the need for urgent measures aimed at the definition of the role of HCTP in society and in the lives of those who are saved: the psychotic-offenders, reviewing the powers of those that act and how these are grounded in order to crystallize any attempt of paradigm change. It is urgent to rethink the work organization so that this become opportunities for creation and realization for the worker and not suffering.

\section{REFERENCES}

1. Goffman E. Manicômios, Prisões e Conventos. 7. ed. São Paulo(SP): Perspectiva; 2003.

2. Carrara SL. Crime e loucura. Rio de Janeiro(RJ): EdUERJ; 1998.

3. Delmanto C. Código Penal comentado. 6. ed. Rio de Janeiro(RJ): Renovar; 2002.

4. Santos MLSC, Souza FS, Santos CVSC. As Marcas da Dupla Exclusão: experiências da enfermagem com o psicótico infrator. Texto Contexto Enferm. [periódico na Internet]. 2006 [acesso em 2011 Nov 21]; 15 (Esp):79-87. Disponível em: http://www.scielo.br/pdf/tce/v15nspe/v15nspea09.pdf.

5. Roese A, Souza AC, Porto GB, Colomé ICS, Costa LED. A produção do conhecimento na enfermagem: desafios na busca de reconhecimento no campo interdisciplinar. Rev Gaúcha Enferm [periódico na Internet]. 2005 dez [acesso em 2012 jan 03]; 26(3): 302-7. Disponível em: http://seer.ufrgs.br/RevistaGauchadeEnfermagem/article/view/4560.

6. Tavares CMM. A interdisciplinaridade como requisito para a formação da enfermeira psiquiátrica na perspectiva da atenção psicossocial. Texto Contexto Enferm. 2005; 14(3):403-410.

7. Meireles BHS, Erdmann AL. A questão das disciplinas e da interdisciplinaridade como processo educativo na área da saúde. Texto Contexto Enferm. [periódico na Internet].1999 Jan-Abr.[acesso em 2012 jan 03]; 8(1):149-65. Disponível em: http://bases.bireme.br/cgi- 
bin/wxislind.exe/iah/online/?lsisScript=iah/iah.xis\&src=google\&base=LILACS\&lang=p\&nextA ction=lnk\&texprSearch=475496\&indexSearch=ID.

8. Ministério da Saúde (Brasil), Secretaria de Atenção à Saúde, DAPE, Coordenação Geral de Saúde Mental. Reforma psiquiátrica e política de saúde mental no Brasil. Documento apresentado à Conferência Regional de Reforma dos Serviços de Saúde Mental: 15 anos depois de Caracas. OPAS. Brasília: Ministério da Saúde, 2005. Disponível em: http://www.ccs.saude.gov.br/vpc/reforma.html.

9. Brasil. Lei $n^{\circ} 8.080$, de 19 de setembro de 1990. Dispõe sobre as condições para promoção, proteção e recuperação da saúde, a organização e o funcionamento dos serviços correspondentes e dá outras providências. Ministério da Saúde (BR); 2000.

10. Minayo MCS. O Desafio do conhecimento: Pesquisa qualitativa em saúde. São Paulo(SP): Huctec; 2007.

11. Polit DF, Beck CT, Hungler BP. Fundamentos de pesquisa em enfermagem: métodos, avaliação e utilização. 5. Ed. São Paulo(SP): Artmed; 2004.

12. Ministério da Saúde (Brasil). Conselho Nacional de Saúde. Resolução 196, de 10 de Outubro de 1996. Diretrizes e normas Regulamentadoras da pesquisa envolvendo seres humanos. Brasília: Minstério da Saúde; 1996.

13. Dejours C. A loucura do Trabalho: estudo de psicopatologia do trabalho. São Paulo(SP): Cortez; 1992.

14. Morin E. Introdução ao Pensamento Complexo. 4 ed. Porto Alegre(RS): Sulina; 2011.

15- Bork AMT. Enfermagem Baseada em Evidências. Rio de Janeiro: Guanabara Koogan; 2005.

16. Severo SB, Seminotti $N$. Integralidade e transdisciplinaridade em equipes multiprofissionais na saúde coletiva. Ciênc Saúde Coletiva. [periódico na Internet]. 2010 jun [acesso em 2012 Feb 11] 15(supl.1): 1685-98. Disponível em: http://www.scielo.br/scielo.php?script=sci_arttext\&pid=\$1413-81232010000700080.

17. Etges NJ. Ciência, interdisciplinaridade e educação. In: Jantsch AP, Bianchetti L, orgs. Interdisciplinaridade: para além do sujeito. Petrópolis(RJ): Vozes;1995. p.51-84.

18. Morin E. Ciência com consciência. 14. ed. Rio de Janeiro(RJ): Bertrand Brasil; 2010. 